\title{
The Mechanisms of the Cholinergic Anti-inflammatory Pathway after Acute Intoxication of Organophosphorus Compounds
}

\author{
Pavel F Zabrodskii* \\ Saratov Branch of the "REAVIZ" Samara Medical Institute, Russia
}

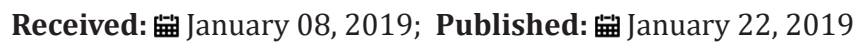

*Corresponding author: Zabrodskii PF, Saratov Branch of the "REAVIZ" Samara Medical Institute, Saratov, Russia

\begin{abstract}
It was established in experiments on random-bred albino mice that the reduction of mortality of mice from sepsis and decrease the blood concentration of proinflammatory cytokines (TNF- $\alpha$, IL- $1 \beta$, IL-6) after acute intoxication of organophosphorus compounds - OPC (DDVP, 0.5 LD ${ }_{50}$ ) due to the implementation of the cholinergic anti-inflammatory pathway: activation of m1-muscarinic acetylcholine receptors a of the brain and $\alpha 7 \mathrm{n}$-acetylcholine receptors of monocyte-macrophage system. The anti-inflammatory effect after acute intoxication of OPC is also associated with the excitation of the sympathetic nervous system, $\beta 2$ adrenergic receptors of $\mathrm{T}$ lymphocytes, macrophages and monocytes and the subsequent reduction in blood of proinflammatory cytokines.
\end{abstract}

Keywords: Organophosphorus Compounds; M1-Muscarinic Acetylcholine Receptors; A7n-Acetylcholine Receptors; $\beta 2$ Adrenergic Receptors; Proinflammatory Cytokines

Abbreviations: IOPC: Organophosphate Compounds; ELISA: Enzyme Immunosorbent Assay; DMSO: Dimethyl Sulfoxide

\section{Introduction}

Organophosphate compounds (OPC) are widely used in agriculture, various industries and households, can cause environmental pollution, as well as acute and chronic intoxications [1-3]. Anticholinesterase drugs used in medicine have almost the same toxicodynamics as OPC [2-5]. More than 200 thousand people per year die from organophosphate insecticide intoxications in the world, mainly as a result of poisoning when used with safety violations [6]. The possibility of using OPC. in local armed conflicts for terrorist and criminal purposes is not excluded [2,6-8], and the occurrence of emergency situations at facilities engaged in the destruction of chemical weapons, in particular OPC, in accordance with international agreements [2,3]. In this case, possible group and mass acute intoxications of OPC [2,3]. Acute and chronic OPC intoxications reduce the humoral and cellular immune response [2,3], however, the study of the mechanisms of realization established by the 1987 "paradoxical effect" of OPC deserves attention-cholinergic stimulation significantly reduced the mortality of mice from sepsis [9]. Thus, we discovered the cholinergic anti-inflammatory mechanism (effect).

Subsequently, the expediency of using cholinomimetics for emergency activation of non-specific antimicrobial resistance of the organism was proved [10], and the identified phenomenon (mechanism) [9], began to be called since 2000 the "cholinergic anti-inflammatory pathway" [2,10,11-14]. Cholinergic antiinflammatory pathway includes: acetylcholine (ACh) activation m1-acetylcholine receptors (m1AChRs) of the brain, modulating the immunoregulatory function of the vagus nerve [15-17], excitation of efferent fibers $n$. vagus; the effect of ACh on $\alpha 7 n$-acetylcholine receptors ( $\alpha 7 \mathrm{nAChRs)}$ of monocyte-macrophage system cells (MMS); inhibition of proinflammatory cytokine production by these cells, TNF- $\alpha$, IL-1 $\beta$, IL-6 [2,16-21] and a decrease in mortality from sepsis $[2,9,10,13,19,21-24]$. When implementing the cholinergic anti-inflammatory pathway, in addition to the effects described, nAChRs of the adrenal medulla and sympathetic ganglia are activated, which leads to the production of epinephrine and norepinephrine (NE), which excite the $\beta 2$-adrenoreceptor ( $\beta 2 \mathrm{ARs}$ ) of MMS cells $[12,21,22]$ and reduce the production of inflammatory cells cytokines [12,13, 19,21,22].

n. vagus, releasing ACh in the celiac ganglia, causes excitation of the nerve of the spleen belonging to the sympathetic nervous system activating the $\alpha 7 \mathrm{nAChRs}$ of the celiac ganglion [16,19,21,22]; NE is affected through its efferent fibers on $\beta 2 \mathrm{ARs}$ of T-lymphocytes 
$[16,21,22]$, the production of ACh by these lymphocytes, which acts on $\alpha 7 \mathrm{nAChRs}$ of MMS cells of the spleen; there is a reduction in the synthesis of proinflammatory cytokines $[12,16,17,18,19]$. Based on the foregoing, it is of interest to study the role of various links units of the cholinergic anti-inflammatory pathway during intoxication of OPC - m1AChRs of the brain, modulating the immunoregulatory function of the vagus nerve [16,17], as well as the associated sympathetic nervous system (the role of $\beta 2$ ARs of $T$ lymphocytes and MMS cells) $[12,13,18,21,22]$, activation of $\alpha 7 n$ AChRs of MMS cells in providing resistance to sepsis and inflammatory bowel diseases [2,10,18, 19,21].

\section{Aim of the study}

The aim of the study was to determine the implementation mechanisms of the cholinergic anti-inflammatory pathway after acute intoxication with organophosphorus compounds by comparative assessment influences OPC and m1AChRs agonist, $\alpha 7 \mathrm{nAChRs}$ agonist, epinephrine, norepinephrine, $\beta 2$ ARs agonist on mortality of mice after sepsis and concentration of proinflammatory cytokines in the blood.

\section{Materials and Methods}

Experiments were performed on random-bred albino mice of both sexes weighing 18-22g. Control group of mice (control group $1, \mathrm{n}=8$ ) received i.p. $2.0 \mathrm{ml}$ isotonic sodium chloride solution (saline) 2 hours after subcutaneous administration of $0.5 \mathrm{ml}$ saline. The second group of mice (control group 2, $\mathrm{n}=55$ ) was injected subcutaneously once with saline $(0.5 \mathrm{ml})$, after $2 \mathrm{~h}$ mice received $2.5 \times 109$ CFUs in $2.0 \mathrm{ml}$ of saline diurnal culture of E. coli 0157:H7 (sepsis modeling) $[2,9,17,18,21,24,25]$. Mice of the third group ( $\mathrm{n}=30$ ) were injected with OPC - DDVP (0, 0-dimethyl-0-2,2dichlorovinyl phosphate) (Sigma-Aldrich) intramuscularly once at a dose of 0.5 LD50 in $0.5 \mathrm{ml}$ of a $0.25 \%$ solution of dimethyl sulfoxide (DMSO). DDVP was dissolved in DMSO, a 0.25\% aqueous solution containing a toxicant was prepared. The $\mathrm{LD}_{50}$ DDVP was $52.5 \pm 3.3 \mathrm{mg} / \mathrm{kg}$. ТВPB [1-(1'-2-methylbenzyl)-1,4'-bipiperidin-4yl)-1H-benzo[d]imidazol-2(3H)-one] (Sigma-Aldrich) was used as a selective m1AChR agonist in the 4 th group of animals $(n=40)$, which was administered once subcutaneously at a dose of $60 \mathrm{mg} /$ $\mathrm{kg}$ [26]. The fifth group of mice $(\mathrm{n}=35)$ received the $\alpha 7 \mathrm{nAChR}$ agonist drug GTS-21 [3- (2,4-dimethoxybenzylidene)-anabaseine dihydrochloride] (Sigma-Aldrich) at a dose of $10 \mathrm{mg} / \mathrm{kg}$ in $0.5 \mathrm{ml}$ saline (single subcutaneous injection) [27]. The sixth $(n=35)$ and seventh groups of mice $(n=33)$ received solutions of epinephrine hydrochloride and norepinephrine hydrotartrate (Sigma-Aldrich) in equitherapeutic doses subcutaneously, once in doses of 0.5 $\mathrm{mg} / \mathrm{kg}$ and $0.9 \mathrm{mg} / \mathrm{kg}$, respectively, in $0.5 \mathrm{ml}$ of physiological solution (activation of $\beta 2$ ARs of T-lymphocytes and MMS cells $[12,16,18,21,22]$.

The eighth group of mice were injected single subcutaneous $\beta 2$ ARs selective agonist hexoprenaline sulfate (Nycomed) at a dose of $1.5 \mathrm{mg} / \mathrm{kg}$ in $0.5 \mathrm{ml}$ of saline (group $3 ; \mathrm{n}=38$ ). In groups $3,4,5$, 6,7 and $8,2 \mathrm{~h}$ after drug administration was sepsis modeling. The mortality of mice (groups 2-8) after sepsis modeling was recorded after 4 and 24 h. The concentration of TNF- $\alpha$, IL1 $\beta$ and IL- 6 was studied in blood plasma of all groups of mice (groups 1-8) 4 and $24 \mathrm{~h}$ after the administration of E. coli (sepsis modeling) by enzyme immunosorbent assay (ELISA) using kits (ELISA Kits My Bio Soure) in accordance with the manufacturer's instructions. Monoclonal antibodies MyBioSoure (TNF- $\alpha$, IL1 $\beta$, IL-6 - \#MBS494184, \#MBS494492, \#MBS335516) were used to determine the concentration of proinflammatory cytokines. Blood for research was taken from the retroorbital venous sinus. The data obtained were processed statistically using the Student's t-test. Differences between the parameters were considered reliable at $\mathrm{p}<0.05$.

\section{Results}

Acute intoxication of OPC (DDVP), the use of m1AChRs agonists (TBPB), an $\alpha 7 n$ AChRs agonist (GTS-21), epinephrine, norepinephrine and agonist $\beta 2$ ARs (hexoprenaline sulfate) 2 hours before the modeling of sepsis caused a significant decrease in mortality after 4 hours compared with the control group 2 (sepsis), respectively, in $364 ; 2.08 ; 2.55 ; 3.19 ; 2.39$ and 1.98 times $(\mathrm{p}<0.05)$ (by $26.4 ; 18.9 ; 22.1 ; 25.0 ; 21.2$ and $18.0 \%$ ), and after $24 \mathrm{~h}-$ in 1.50 ; $1.57 ; 1.75 ; 1.97 ; 1.80$ and 1.56 times (by $30.1 ; 32.6 ; 38.7 ; 44.4 ; 40.1$ and $32.2 \%$ ) ( $\mathrm{p}<0.05)$, respectively (Table 1$)$. The concentrations of cytokines TNF- $\alpha$, IL- $1 \beta$ and IL- 6 after sepsis modeling (control group 2) significantly increased in the blood of mice after $4 \mathrm{~h}$ compared to control group 1 (intact animals), respectively, at 17.8; 19.5 and 57.7 times $(\mathrm{p}<0.05)$, the concentrations of TNF- $\alpha$, IL-1 $\beta$ and IL-6 after $24 \mathrm{~h}$ compared with their level after $4 \mathrm{~h}$ significantly decreased, exceeding the parameters of intact animals (group 1 ) in 1.5 ( $\mathrm{p}>0.05), 4.5$ and 8.2 times ( $<<0.05$ ), respectively (Table 2 ).

Table 1: Effects of OPC (DDVP, 0.5 LD50), m1AChRs agonist TBPB (60 mg/kg), a7nAChRs agonist GTS-21 (10 mg/kg), epinephrine $(0.5 \mathrm{mg} / \mathrm{kg})$, norepinephrine $(0.9 \mathrm{mg} / \mathrm{kg})$ and agonist $\beta 2 \mathrm{ARs}$ hexoprenaline sulfate $(1.5 \mathrm{mg} / \mathrm{kg})$ on the mortality of mice from sepsis $(\mathrm{M}+\mathrm{m})$.

\begin{tabular}{|c|c|c|}
\hline \multirow{2}{*}{ Series of Experiments } & \multicolumn{2}{|c|}{ Term study of mortality after the introduction of $E$. coli, h } \\
\hline & 4 & 24 \\
\hline Sepsis (control group $2, \mathrm{n}=55$ & $36,4 \pm 6,5$ & $90,1 \pm 4,0$ \\
\hline DDVP + sepsis (group $3, n=30$ ) & $10,0 \pm 5,5^{*}$ & $60,0 \pm 8,9^{*}$ \\
\hline Agonist m1AChRs (ТВРВ) + сепсис (группа 4, n = 40) & $17,5 \pm 6,1^{*}$ & $57,5 \pm 7,8^{*}$ \\
\hline Agonist $\alpha 7$ nAChRs (GTS-21) + sepsis (group 5, n = 35) & $14,3 \pm 5,9^{*}$ & $51,4 \pm 8,4^{*}$ \\
\hline Epinephrine + sepsis (group 6, $n=35$ ) & $11,4 \pm 5,2^{*}$ & $45,7 \pm 8,5^{*}$ \\
\hline Norepinephrine + sepsis (group $7, \mathrm{n}=33$ ) & $15,2 \pm 6,2^{*}$ & $50,0 \pm 9,1^{*}$ \\
\hline Agonist $\beta^{2}$ ARs - hexoprenaline sulfate + sepsis (group $8, n=38$ ) & $18,4 \pm 6,2^{*}$ & $57,9 \pm 8$ \\
\hline
\end{tabular}


Note:*-p $<0,05$ as compared to control (group 2).

Table 2: Effects of OPC (DDVP, 0.5 LD50), m1AChRs agonist TBPB (60mg/kg), a7nAChRs agonist GTS-21 (10mg/kg), epinephrine $(0.5 \mathrm{mg} / \mathrm{kg})$, norepinephrine $(0.9 \mathrm{mg} / \mathrm{kg})$ and agonist $\beta 2 \mathrm{ARs}$ hexoprenaline sulfate $(1.5 \mathrm{mg} / \mathrm{kg})$ on concentrations of proinflammatory cytokines in blood of mice with E. coli sepsis, $\mathrm{pg} / \mathrm{ml}(\mathrm{M} \pm \mathrm{m} ; \mathrm{n}=6-8)$.

\begin{tabular}{|c|c|c|c|c|c|c|}
\hline \multirow{2}{*}{ Series of experiments } & \multicolumn{2}{|c|}{$\Phi \mathrm{HO \alpha}$} & \multicolumn{2}{|c|}{ ИЛ1 $\beta$} & \multicolumn{2}{|c|}{ ил-6 } \\
\hline & 4 & 24 & 4 & 24 & 4 & 24 \\
\hline Control group 1 & $34 \pm 5$ & $36 \pm 5$ & $26 \pm 4$ & $28 \pm 5$ & $33 \pm 6$ & $25 \pm 4$ \\
\hline Sepsis (control group 2) & $606 \pm 84^{\mathrm{a}}$ & $55 \pm 8^{c}$ & $507 \pm 68^{\mathrm{a}}$ & $125 \pm 21^{\text {ac }}$ & $1905 \pm 243^{\mathrm{a}}$ & $205 \pm 34^{\text {ac }}$ \\
\hline DDVP + sepsis (group 3) & $230 \pm 29^{a b}$ & $41 \pm 6^{c}$ & $228 \pm 33^{\text {ab }}$ & $52 \pm 7^{\text {abc }}$ & $305 \pm 40^{\mathrm{ab}}$ & $85 \pm 10^{\text {abc }}$ \\
\hline Agonist m1AChRs (TBPB) + sepsis (group 4) & $205 \pm 33^{\mathrm{ab}}$ & $39 \pm 6^{c}$ & $215 \pm 29^{\mathrm{ab}}$ & $70 \pm 11^{\mathrm{abc}}$ & $255 \pm 37^{\mathrm{ab}}$ & $90 \pm 12^{\text {abc }}$ \\
\hline Agonist $\alpha 7$ nAChRs (GTS-21) + sepsis (group 5) & $178 \pm 32^{\mathrm{ab}}$ & $35 \pm 7^{\mathrm{bc}}$ & $190 \pm 22^{\mathrm{ab}}$ & $57 \pm 8^{\text {abc }}$ & $244 \pm 38^{\mathrm{ab}}$ & $74 \pm 9^{\text {abc }}$ \\
\hline Epinephrine + sepsis (group 6) & $197 \pm 30^{\mathrm{ab}}$ & $50 \pm 7^{c}$ & $200 \pm 33^{\mathrm{ab}}$ & $48 \pm 6^{\mathrm{abc}}$ & $204 \pm 25^{\text {ab }}$ & $80 \pm 11^{\text {abc }}$ \\
\hline Norepinephrine + sepsis (group 7) & $180 \pm 29^{\mathrm{ab}}$ & $46 \pm 6^{c}$ & $217 \pm 34^{\mathrm{ab}}$ & $75 \pm 10^{\text {abc }}$ & $238 \pm 28^{\mathrm{ab}}$ & $72 \pm 9^{\text {abc }}$ \\
\hline Agonist $\beta 2$ ARs (hexoprenaline sulfate) + sepsis (group 8) & $165 \pm 30^{\mathrm{ab}}$ & $37 \pm 7^{\mathrm{c}}$ & $184 \pm 25^{\mathrm{ab}}$ & $60 \pm 9 \mathrm{abc}$ & $269 \pm 39^{\mathrm{ab}}$ & $65 \pm 10^{\text {abc }}$ \\
\hline
\end{tabular}

Note: 4 and 24 - after sepsis modeling, h; a-p <0,05 as compared to control (group 1); b-p <0,05 as compared to the corresponding parameter in sepsis (control group 2); c-p $<0,05$ as compared to the $4 \mathrm{~h}$.

Acute intoxication of OPC (DDVP) decreased the TNF- $\alpha$, IL-1 $\beta$ and IL- 6 blood concentrations $4 \mathrm{~h}$ after sepsis modeling (group 3 ) compared to the control group 2 (sepsis without the use of drugs), respectively, by $2.6 ; 2.2$ and 6.2 times $(\mathrm{p}<0.05)$. At the same time, the concentrations of proinflammatory cytokines in the blood significantly $(p<0.05)$ exceeded the corresponding parameters of the control group 1 . The concentrations of TNF- $\alpha$, IL-1 $\beta$ and IL-6 $24 \mathrm{~h}$ after sepsis modeling decreased in comparison with these parameters after $4 \mathrm{~h}$, remaining below group 2 values in 1.3 ( $p>0.05$ ), 2.4 and 2.4 times $(p<0.05)$, respectively. The parameters of TNF- $\alpha$, IL-1 $\beta$ and IL- 6 after administration of m1AChRs agonist (TBPB) 4 $\mathrm{h}$ after modeling sepsis (group 4) decreased compared with the parameters of the control group 2, respectively, in 3.0; 2.4 and 8.0 times $(\mathrm{p}<0.05)$. A decrease in blood levels of proinflammatory cytokines was detected $24 \mathrm{~h}$ after sepsis modeling compared with the corresponding values after $4 \mathrm{~h}$, while the concentrations of TNF- $\alpha$, IL-1 $\beta$ and IL- 6 remained below the values of group 2, respectively, in 1.4 ( $\mathrm{p}>0,05) ; 1.8$ and 2.3 times ( $\mathrm{p}<0.05)$.

The values of TNF- $\alpha$, IL- $1 \beta$ and IL- 6 , when using the $\alpha 7 \mathrm{nAChRs}$ agonist (GTS-21), decreased $4 \mathrm{~h}$ after the modeling of sepsis (group 5) compared to the parameters of the control group 2, respectively, in 3.4; 2.7 and 7.8 times $(\mathrm{p}<0.05)$. A reduction of content of proinflammatory cytokines in the blood was established $24 \mathrm{~h}$ after the sepsis modeling compared with the corresponding values after
$4 \mathrm{~h}$, while the concentrations of TNF- $\alpha$, IL- $1 \beta$ and IL- 6 remained below the values of group 2, respectively, in 1.6 ( $p>0,05) ; 2.2$ and 2.8 times $(p<0.05)$. Epinephrine reduced the TNF- $\alpha$, IL- $1 \beta$ and IL-6 blood concentrations $4 \mathrm{~h}$ after the sepsis modeling (group 6) compared with the control group 2 (sepsis), respectively, in $3.1 ; 2.5$ and 9.3 times $(\mathrm{p}<0.05)$. IL-1 $\beta$ and IL- 6 values after $24 \mathrm{~h}$ decreased in 2.6 and 2.5 times ( $\mathrm{p}<0.05)$, respectively, compared with these parameters in group 2, and the level of TNF- $\alpha$ in the blood did not significantly change. After administration NE the TNF- $\alpha$, IL$1 \beta$ blood levels there was a reduction $4 \mathrm{~h}$ after sepsis modeling (group 7) compared with the control group 2 (sepsis), respectively, in $3.4 ; 1.7$ and 8.0 times ( $p<0.05$ ). The IL- $1 \beta$ and IL- 6 blood concentrations were reduced after $24 \mathrm{~h}$ compared to the values after $4 \mathrm{~h}$, respectively, 1.7 and 2.8 times $(\mathrm{p}<0.05)$, and the content of TNF- $\alpha$ remained almost unchanged.

The parameters of TNF- $\alpha$, IL- $1 \beta$ and IL- 6 after administration of $\beta 2$ ARs agonist (hexoprenaline sulfate) $4 \mathrm{~h}$ after sepsis modeling (group 8) decreased compared with the parameters of the control group 2, respectively, in 3.7; 2.8 and 7.1 times $(\mathrm{p}<0.05)$. A decrease in blood levels of proinflammatory cytokines was detected $24 \mathrm{~h}$ after sepsis modeling compared with the corresponding values after $4 \mathrm{~h}$, while the concentrations of TNF- $\alpha$, IL-1 $\beta$ and IL- 6 remained below the values of group 2, respectively, in 1.5 ( $p>0,05) ; 2.1$ and 3.2 times $(p<0.05)$. The IL- $1 \beta$ and IL-6 blood concentrations in 
groups 3, 4, 5, 6, 7 and 8 were significantly higher $(\mathrm{p}<0.05)$ than the corresponding values of the control group 1 . The TNF- $\alpha$, IL-1 $\beta$ and IL- 6 blood concentrations after acute intoxication of OPC, the effects of the agonist m1AChRs (TBPB), $\alpha 7 n A C h R$ agonist (GTS21), epinephrine, NE and $\beta 2 A R s$ agonist (hexoprenaline sulfate) after modeling sepsis $2 \mathrm{~h}$ after administration of OPC (DDVP) and these drugs (groups $3,4,5,6,7,8$ ) decreased approximately equally compared with the reduction after the modeling sepsis (group 2; without the use of drugs).

\section{Discussion}

After acute OPC intoxication, exposure to the m1AChRs agonist (TBPB), $\alpha 7 n A C h R s$ agonist (GTS-21), epinephrine, NE and agonist $\beta 2$ ARs (hexoprenaline sulfate) $2 \mathrm{~h}$ after sepsis modeling (groups $3,4,5,6,7,8$ ) there was no significant difference in the mortality of mice. This suggests that the mechanism of action of OPC, which causes a decrease in animal mortality after sepsis, is associated with acetylcholine m1AChRs activation of the brain [16,17], $\alpha 7 \mathrm{nAChRs}$ of MMS cells, nAChRs of adrenal medulla $[2,13,16,18,21,22]$, as well as activation of epinephrine, NE and agonist $\beta 2 \mathrm{ARs}$ (hexoprenaline sulfate) of $\beta 2 A R s$ of MMS cells [21,22] due to the excitation of the ganglia of the sympathetic nervous system $[2,18,21]$.

There is reason to conclude that the mechanism for reducing mortality in mice with acute intoxication of OPC from sepsis is due to activation in the brain m1AChRs (the first link of the cholinergic anti-inflammatory pathway) [2,16,17], $\alpha 7 n A C h R$ MMS cells $[12,17,19]$, as well as $\beta 2 A R s$ macrophages and monocytes (due to the excitation of the sympathetic nervous system) and the action of norepinephrine on $\mathrm{T}$ lymphocytes of the spleen, $[2,12,13,18]$. The implementation of the reduction of pro-inflammatory cytokines TNF- $\alpha$, IL-1 $\beta$, IL- 6 , and others (the occurrence of anti-inflammatory effect) is provided by JAK2 kinase, STAT3 transcription factor, transcription factor $\mathrm{NF}-\kappa \mathrm{B})[2,12,17-21,22]$. In addition, the decrease in mortality from sepsis after acute intoxication of OPC due to the suppression of the synthesis of proinflammatory cytokines is also associated with the effect of corticosteroids (activation of the hypothalamic-pituitary-adrenal system) $[2,3,19,18]$.

\section{Conclusion}

Reduced mortality of mice from sepsis and the blood concentration of proinflammatory cytokines TNF- $\alpha$, IL-1 $\beta$, IL-6 after acute intoxication of organophosphorus compounds is due to the implementation of the cholinergic anti-inflammatory pathway: activation of $\mathrm{m}$-acetylcholinergic receptors type 1 (m1AChRs) of the brain and $\alpha 7 n$-acetylcholine receptors ( $\alpha 7 n A C h R s)$ of the monocyte-macrophage system, as well as stimulation of the sympathetic nervous system, $\beta 2$-adrenoreceptors ( $\beta 2 \mathrm{ARs}$ ) $\mathrm{T}$ lymphocytes, macrophages and monocytes.

\section{References}

1. Tremolada P, Finizio A, Villa S, Gaggi C, Vighi M (2004) Quantitative inter-specific chemical activity in the aquatic environment. Aquatic Toxicology 67(1): 87-103.

2. PF Zabrodskii (2016) Immunotoxicology of organophosphorus compounds. Saratov 289.
3. Zabrodskii PF, Mandych VG (2007) Immunotoxicology of xenobiotics. Saratov Military Institute of Biological and Chemical Safety 420.

4. King AM, Aaron CK (2015) Organophosphate and carbamate poisoning. Emerg Med Clin North Am 33(1): 133-151.

5. Peter JV, Sudarsan TI, Moran JL (2014) Clinical features of organophosphate poisoning: A review of different classification systems and approaches. Indian J Crit Care Med 18(11): 735745.

6. Hulse EJ, Davies JO, Simpson AJ, Sciuto AM, Eddleston M (2014) Respiratory complications of organophosphorus nerve agent and insecticide poisoning. Implications for respiratory and critical care. Am J Respir Crit Care Med 190(12): 1342-1354.

7. Sawyer TW, Mikler J, Worek F, Reiter G, Thiermann H, et al. (2011) The therapeutic use of localized cooling in the treatment of VX poisoning. Toxicol Lett. 204(1): 52-56.

8. Yanagisawa N (2014) The nerve agent sarin: history, clinical manifestations, and treatment". Brain Nerve 66(5): 561-569.

9. Zabrodskii PF (1987) Effect of armin on nonspecific resistance factors of the body and on the primary humoral immune response. Farmakologiia I Toksikologiia 50(1): 57-60.

10.Zabrodskii PF (1995) Change in the non-specific anti-infection resistance of the body exposed to cholinergic stimulation. Bulletin of Experimental Biology and Medicine 120(8): 164-166.

11.Borovikova LV, Ivanova $S$, Zhang $M$, Yang $H$, Botchkina $G$, et al. (2000) Vagus nerve stimulation attenuates the systemic inflammatory response to endotoxin. Nature 405(6785): 458462.

12.Pavlov VA, Wang H, Czura CJ, Friedman SG, Tracey KJ (2003) The cholinergic anti-inflammatory pathway: a missing link in neuroimmunomodulation. Molecular Medicine 9(5-8): 125134.

13. Martelli D, Mc Kinley MJ, Mc Allen RM (2014) The cholinergic anti-inflammatory pathway: a critical review. Auton Neurosci 182: 65-69.

14.Payolla TB, Lemes SF, de Fante T, Reginato A, Mendes da Silva C, et al. (2016) High-fat diet during pregnancy and lactation impairs the cholinergic anti-inflammatory pathway in the liver and white adipose tissue of mouse offspring. Mol Cell Endocrinol 422:192-202.

15.Eftekhari G, Hajiasgharzadeh K, Ahmadi Soleimani SM, Dehpour AR, Semnanian S, et al. (2014) Activation of central muscarinic receptor type 1 prevents development of endotoxin tolerance in rat liver. Eur J Pharmacol 740: 436-441.

16. Rosas Ballina M, Tracey KJ (2009) Cholinergic control of inflammation. J Intern Med 265(6): 663-679.

17.Zabrodskii PF (2017) Combined Effects of M1 Muscarinic Acetylcholine Receptor Agonist TBPB and $\alpha 7 n$-Acetylcholine Receptor Activator GTS-21 on Mouse Mortality and Blood Concentration of Proinflammatory Cytokines in Sepsis. Bulletin of Experimental Biology and Medicine 162(6): 750-753.

18.Bonaz BL, Bernstein CN (2013) Brain-gut interactions in inflammatory bowel disease. Gastroenterology 144(1): 36-49.

19.Zabrodskii PF (2015) Effect of $\alpha 7 n$-Acetylcholine Receptor Activation and Antibodies to TNF- $\alpha$ on Mortality of Mice and 
Concentration of Proinflammatory Cytokines During Early Stage of Sepsis. Bulletin of Experimental Biology and Medicine 159(6): 740-742.

20.Egea J, Buendia I, Parada E, Navarro E, León R, et al. (2015) Antiinflammatory role of microglial alpha7 nAChRs and its role in neuroprotection. Biochem Pharmacol 97(4): 463-472.

21.Zabrodskii PF (2016) Role of $\beta 2$-adrenoreceptors in adrenergic anti-Inflammatory mechanism in sepsis. Bulletin of Experimental Biology and Medicine 162(12): 718-721.

22.Zabrodskii PF, Gromov MS, Maslyakov VV (2018) Combined Effect of NF-kB Inhibitor and $\beta 2$-Adrenoreceptor Agonist on Mouse Mortality and Blood Concentration of Proinflammatory Cytokines in Sepsis. Bulletin of Experimental Biology and Medicine 162(6): 445-448.

23. Kox M, Pickkers P (2015) Modulation of the innate immune response through the vagus nerve. Nephron. 131(2): 79-84.

ISSN: 2574-1241

DOI: 10.26717/BJSTR.2019.13.002399

Zabrodskii PF. Biomed J Sci \& Tech Res

CC (i) This work is licensed under Creative

Submission Link: https://biomedres.us/submit-manuscript.php
24.Zabrodskii PF (2011) Effect of acetylcholine on mortality of mice from sepsis and proinflammatory cytokine production. Bulletin of Experimental Biology and Medicine 150(3): 340-342.

25.Song DJ, Huanq XY, Ren LC, Yang XH, Xiao MZ, et al. (2009) Effect of lentiviral vector encoding on triggering receptor expressed on myeloid cells 1 on expression of inflammatory cytokine in septic mice infected by Bacteroides fragilis. Zhonghua Shao Shang Za Zhi 25(1): 36-41.

26.Jones CK, Brady AE, Davis AA, Xiang Z, Bubser M, et al. (2008) Novel selective allosteric activator of the M1 muscarinic acetylcholine receptor regulates amyloid processing and produces antipsychotic-like activity in rats. J Neurosci 28(41): 10422-10433.

27. Sitapara RA, Antoine DJ, Sharma L, Patel VS, Ashby CR Jr, et al. (2014) The $\alpha 7$ nicotinic acetylcholine receptor agonist GTS-21 improves bacterial clearance in mice by restoring hyperoxiacompromised macrophage function. Mol Med 20: 238-247. 